\title{
The need for and the role of a coordinator in child health surveillance/promotion
}

In an important sense, the clinical consultation is the primary activity of medicine, and its autonomy should be the basic principle around which the health service is organised. ${ }^{1}$

In the case of the individual consultation initiated by the patient, it is relatively clear where the doctor's responsibilities lie in terms of providing a quality service and how this is organised. However, when a consultation is initiated by one or more of the health care team, as part of a nationally prescribed screening programme involving a number of professionals, there is an issue of who takes ultimate responsibility for the quality and delivery of the preventive programme as a whole.

The UN Convention on the Rights of the Child places a clear responsibility on the state to provide access to preventive care, such as maternal and infant health clinics and immunisation (Article 24). The UK has a long history of setting up successful maternal and infant welfare programmes from the turn of the last century, ${ }^{2}$ involving doctors and health visitors with a specific role in this field. The child health surveillance/health promotion programme in the UK is one such nationally prescribed programme developed from professional consensus.

The integration of doctors previously employed by the local authority as medical officers of health working in child health clinics and schools into the NHS structure in 1974 started the move towards a clearer integration of preventive and curative services. With the 1990 NHS Act, the preschool child health surveillance programme for children became an integral part of the general practitioner (GP) contract with the school health programme being maintained by medical officers and school nurses. Pre 1974, there was a strong tradition of child public health, often headed up at district level by a principal medical officer. One of the roles of that individual was to provide an annual report on the state of the children's health in that locality and to take an "overview" of child health in that population, usually making recommendations for action to the next level up of the health service management. Who is providing that overview in the twenty first century?

It could be argued that the vacuum now left in the area of child public health is being filled by paediatricians, senior nurse managers, and public health physicians. The coordination of preventive programmes has been described in Working together for tomorrow's children as one of the key interface tasks for paediatricians involved in child public health. ${ }^{3}$

This task of coordinating the different elements of the child health screening programmes as laid out in the national reports by $\mathrm{Hall}^{4}$ and Polnay ${ }^{5}$ is assumed by paediatricians, usually consultant community paediatricians in over $80 \%$ of districts in the UK. This article explores some of the issues relevant to paediatricians and others who are nominated as child health surveillance coordinators for their health authorities.

\section{What is the recommended child health surveillance (CHS) programme in the UK?}

At the time of writing, the programme is being reviewed by a joint Royal College of Paediatrics and Child Health national working group chaired by $\mathrm{Dr}$ David Elliman, convenor of the British Association of Community Child Health. Table 1 describes the different elements of the current UK policy at the recommended ages as recommended by the last national working group. This programme encompasses components of screening, immunisation, monitoring and oversight, individual health education/health promotion, and population based health promotion. The various constituents are based on the best evidence to date. Who does what formally is very much a local decision and has not been prescribed. Many individuals are involved informallyparents, teachers, children, and young people. In order to coordinate the programme so that it can be effectively delivered and monitored, a number of functions need to be considered.

\section{The district CHS group and its functions}

Many stakeholders are involved in child health surveillance and it is advisable to create a multidisciplinary steering group to reflect this. The definition of the duties, the appointments of the individuals responsible for these coordinating functions should be a joint undertaking of the commissioning and purchasing authorities and the provider units. The responsibilities of the group and individuals should be clearly defined so that the questions or concerns about any service or programme can be directed promptly to one person.

The suggested membership of the district wide CHS steering group should include a community paediatrician, a public health clinician with special responsibility for children, preventive care group lead, health visitor professional lead, child protection lead, school nurse professional lead, hospital paediatrician, health promotion specialist, administration/information technology lead for health community, parent representative Community Health Council (CHC). The chairperson of this group is known as the district child health surveillance programme coordinator. The six functions of the steering group are detailed below.

(1) TO SHARE OWNERSHIP OF THE PROGRAMME AND TO DEVELOP AGREED WRITTEN AIMS, OBJECTIVES, REFERRAL GUIDELINES, ADMINISTRATIVE PROCESSES, AND TRAINING STANDARDS

This should be encapsulated in a district wide policy document available to all those who require it. Clear referral guidelines need to be produced by a variety of secondary care providers-paediatric general and orthopaedic surgeons, cardiologists, audiologists, psychologists, and psychiatrists - to ensure that those in primary care know what to do once a screen is positive or a case is suspected. It would be advisable for guidelines to be produced for referrals within primary care teams, for example, between health visitors and GPs, receptionists, practice nurses for problems such as feeding difficulties, immunisation queries, developmental concerns. This 
Table 1 Summary of recommended UK child health programme

\begin{tabular}{|c|c|c|c|}
\hline Age & Review and screening procedures & Immunisation & Health promotion \\
\hline Newborn & $\begin{array}{l}\text { Review: } \\
\text { Family history } \\
\text { Pregnancy } \\
\text { Birth } \\
\text { Full physical examination including: } \\
\text { Weight } \\
\text { Heart and pulses } \\
\text { Hips } \\
\text { Birth marks } \\
\text { Testes } \\
\text { Head circumference plotted } \\
\text { Eyes (exclude cataracts and squint) } \\
\text { Guthrie test after } 6 \text { days (PKU, hypothyroidism) } \\
\text { Sickle cell (if indicated) } \\
\text { Consider: } \\
\text { Risk factors for hearing loss } \\
\text { Refer to Can your baby hear you in PHCHR } \\
\text { If high risk then refer for otoacoustic emission, brainstem } \\
\text { auditory evoked response }\end{array}$ & $\begin{array}{l}\text { BCG (high risk) } \\
\text { Hep B (if mother is a carrier) }\end{array}$ & $\begin{array}{l}\text { Cot death prevention } \\
\text { Feeding technique } \\
\text { Nutrition } \\
\text { Baby care } \\
\text { Crying } \\
\text { Sleep } \\
\text { Car safety } \\
\text { Family planning } \\
\text { Passive smoking } \\
\text { Dangers of shaking baby } \\
\text { Sibling management }\end{array}$ \\
\hline $10-14$ days & $\begin{array}{l}\text { Guided by results and review of neonatal check } \\
\text { Assess and establish levels of support and assistance } \\
\text { required } \\
\text { Review sickle cell and thalassaemia test (if appropriate) }\end{array}$ & $\begin{array}{l}\text { Review BCG and Hep B status } \\
\text { Introduce to immunisation } \\
\text { programme and obtain informed } \\
\text { consent }\end{array}$ & $\begin{array}{l}\text { Nutrition } \\
\text { Breast feeding } \\
\text { Passive smoking } \\
\text { Accident prevention: bathing, scalding and fires } \\
\text { Explanation of tests and results } \\
\text { Encouraging parents to request results of all tests } \\
\text { Significance of prolonged jaundice } \\
\text { Depression, coping and help (parents/carers) }\end{array}$ \\
\hline 6-8 weeks & $\begin{array}{l}\text { Review: } \\
\text { Parental concerns, e.g. vision, hearing, activity } \\
\text { Risk factors including significant family history } \\
\text { Full examination including: } \\
\text { Weight } \\
\text { Head circumference } \\
\text { Length } \\
\text { Centile plotting } \\
\text { Hip check } \\
\text { Testes } \\
\text { Eyes: red reflex, squint, movement, tone and general } \\
\text { development } \\
\text { Heart and pulses } \\
\text { Report Guthrie results back to parents }\end{array}$ & $\begin{array}{l}\text { 1st DT Pert Hib/Pol } \\
\text { Meningococcal C }\end{array}$ & $\begin{array}{l}\text { Immunisation } \\
\text { Nutrition and dangers of early weaning } \\
\text { Accidents: fires, falls, overheating, scalds } \\
\text { Refer parent to Can your baby hear you? in PHCHR } \\
\text { Recognition of illness in babies and what to do } \\
\text { Fever management } \\
\text { Crying } \\
\text { Sleeping position } \\
\text { Passive smoking } \\
\text { Review of car safety } \\
\text { Depression (parents/carers) }\end{array}$ \\
\hline $2-4$ months & Parental concerns & $\begin{array}{l}\text { 2nd and 3rd DT Pert Hib/Pol } \\
\text { Meningococcal C }\end{array}$ & $\begin{array}{l}\text { Weighing as appropriate } \\
\text { Maintain previous health promotion } \\
\text { Promotion of language and social development } \\
\text { Refer parent to Can your baby hear you? in PHCHR } \\
\text { Deter future use of baby walkers }\end{array}$ \\
\hline 6-9 months & $\begin{array}{l}\text { Hip check } \\
\text { Distraction hearing test (catch up for missed neonatal } \\
\text { screen, infants moving in) } \\
\text { Discussion of developmental progress, asking specifically } \\
\text { about vision, hearing and language development } \\
\text { Check weight and head circumference as required or if } \\
\text { parental concern } \\
\text { Observe behaviour and look for squints }\end{array}$ & & $\begin{array}{l}\text { Parental concerns } \\
\text { Nutrition } \\
\text { Refer parent to Can your baby hear you? in PHCHR } \\
\text { Accident prevention: fires, choking, scalding, burns, } \\
\text { gate guard etc } \\
\text { Review of transport in cars } \\
\text { Dental care } \\
\text { Play and development needs }\end{array}$ \\
\hline 13 months & & MMR & \\
\hline $18-24$ months & $\begin{array}{l}\text { Parental concerns, behaviour, vision and hearing } \\
\text { Observe gait } \\
\text { Emphasise value of comprehension and social } \\
\text { communication in relation to speech development } \\
\text { (speech and language screening tests) } \\
\text { Measure height and plot }\end{array}$ & Review immunisation status & $\begin{array}{l}\text { Safety: } \\
\text { Accident prevention: falls from heights, drowning, } \\
\text { poisoning, road safety } \\
\text { Development: } \\
\text { Language and play } \\
\text { Management and behavioural issues } \\
\text { Promote positive parenting } \\
\text { Toilet training } \\
\text { Diet, nutrition, prevention of iron deficiency }\end{array}$ \\
\hline 39-42 months & $\begin{array}{l}\text { Enquiry and discussion of vision, squint, hearing, } \\
\text { behaviour, language acquisition, development-referral } \\
\text { as necessary } \\
\text { Education needs and choices } \\
\text { Notification of any special educational needs and choices } \\
\text { Measure height and plot } \\
\text { Check testicular descent has been recorded, if not } \\
\text { examine } \\
\text { Where concerns re: hearing impairment, perform test } \\
\text { (e.g. McCormick toy discrimination test) }\end{array}$ & $\begin{array}{l}\text { DT/polio (preschool booster) } \\
\text { 2nd MMR }\end{array}$ & $\begin{array}{l}\text { Accident prevention: burns, road safety, drowning, } \\
\text { poisoning, falls from heights } \\
\text { Development: } \\
\text { Language and play socialisation } \\
\text { Management of behaviour issues } \\
\text { School readiness } \\
\text { Nutrition/diet } \\
\text { Dental care } \\
\text { Toilet training }\end{array}$ \\
\hline
\end{tabular}


Table 1 continued

\begin{tabular}{|c|c|c|c|}
\hline Age & Review and screening procedures & Immunisation & Health promotion \\
\hline $\begin{array}{l}5 \text { years school } \\
\text { entrant }\end{array}$ & $\begin{array}{l}\text { Review preschool record including a check for record of } \\
\text { testicular and heart examination } \\
\text { School entrant review-parent and school nurse } \\
\text { Establish teachers/parental concerns } \\
\text { Height (plot and compare with previous measurements), } \\
\text { weight and hearing sweep } \\
\text { Visual acuity (Snellen) } \\
\text { Observation of gait and fine motor skills }\end{array}$ & Review of immunisation status & $\begin{array}{l}\text { Obtain consent for planned programme and health } \\
\text { checks } \\
\text { Access to school health } \\
\text { School health surveillance programme } \\
\text { Sleep } \\
\text { Friendships/settling at school } \\
\text { Accident prevention, road safety, stranger danger } \\
\text { Dentist, dietician } \\
\text { Management of medicines at school } \\
\text { Care in the sun }\end{array}$ \\
\hline $\begin{array}{l}\text { Year } 3 \\
7-8 \text { years }\end{array}$ & $\begin{array}{l}\text { Teacher concerns } \\
\text { Review of records } \\
\text { Height, weight, vision } \\
\text { General health check } \\
\text { Issues raised by child }\end{array}$ & & $\begin{array}{l}\text { Accident prevention, road safety, safety at play, } \\
\text { stranger danger } \\
\text { Friendships } \\
\text { Exercise, nutrition and dental care } \\
\text { Care in the sun }\end{array}$ \\
\hline $\begin{array}{l}\text { Year } 7 \\
11-12 \text { years }\end{array}$ & $\begin{array}{l}\text { Visual acuity } \\
\text { Colour vision } \\
\text { General health check } \\
\text { Issues raised by young person } \\
\text { Support for individual programmes of care }\end{array}$ & & $\begin{array}{l}\text { Accident prevention } \\
\text { Relationships } \\
\text { Exercise/nutrition } \\
\text { Smoking } \\
\text { Dental care } \\
\text { Management of medication in school } \\
\text { Puberty/sexual health } \\
\text { Care in the sun }\end{array}$ \\
\hline $\begin{array}{l}\text { Year } 8 \\
12-13 \text { years }\end{array}$ & & $\begin{array}{l}\text { Heaf Test } \\
\text { BCG }\end{array}$ & \\
\hline $\begin{array}{l}\text { Year } 10 \\
14-15 \text { years }\end{array}$ & $\begin{array}{l}\text { General health check including height, weight, vision } \\
\text { where concerns } \\
\text { Issues raised by young person }\end{array}$ & $\mathrm{Td} /$ polio booster & $\begin{array}{l}\text { Substance abuse-alcohol, smoking, drugs, solvents } \\
\text { Diet/exercise } \\
\text { Testicular self examination, promotion of cervical } \\
\text { cytology } \\
\text { Sexual health } \\
\text { Promotion of general practitioner well woman/man } \\
\text { check } \\
\text { Information about health services, e.g. } \\
\text { Teenage clinics } \\
\text { Health shop } \\
\text { Dental health } \\
\text { Careers } \\
\text { Stress management }\end{array}$ \\
\hline $\begin{array}{l}\text { Year } 11 \\
15-16 \text { years }\end{array}$ & Self referral—issues raised by students & $\begin{array}{l}\text { Information to school leavers on } \\
\text { need for immunisations as adult } \\
\text { catch up immunisation }\end{array}$ & Self referral—issues raised by students \\
\hline
\end{tabular}

would help strengthen a recognition of each other's expertise in this setting. It is useful to have intelligence outside the group nationally and internationally to ascertain the most up to date evidence base and ensure that the policy and referral guidelines are updated accordingly.

There is a need to protect children from avoidable harm and the health authority and providers from litigation. The emergence of clinical and corporate governance has highlighted the importance of training in ensuring delivery of high quality services which should minimise harm. Standards need to be set in this area and staff regularly updated. This is an area for future development with staff being expected to attain different levels of competencies depending on their role in the system. This could form the basis of a local certificate in child health surveillance which would be required by all staff involved in this activity. Training in CHS might also contribute to the National Vocational Qualification (NVQ) scheme. It is also important that day nursery and social worker training and orientation is arranged so that there is a familiarity with the main components of the child health surveillance programme. This is of particular relevance in the light of moves to improve the health status of "looked after" children. GPs working in areas with a high prevalence of child abuse and neglect may benefit from a more focused and local training approach. ${ }^{6}$

(2) TO DEVELOP QUALITY STANDARDS FOR PROVISION OF CHS IN PRIMARY CARE AND SCHOOL AND METHODS FOR MONITORING THESE

Table 2 is an example of such standards (preschool) set by an interprofessional group of GPs, health visitors, and community paediatricians. Methods of monitoring include coverage and timeliness of individual screening reviews via parent held record returns and validation with clinical notes, practice visits to discuss equipment, administrative and management processes, and feedback of performance and parent questionnaire. ${ }^{7}$ In view of the rarity of conditions being screened for, periodic detailed review of critical adverse incidents is a useful method of audit to ascertain lessons for future action. ${ }^{8}$

Critical incidents can also be used for teaching-an examination of local data on "late" diagnosed hip developmental dysplasia indicated the presence of early physical signs which were ignored, and reiterated the need to hone physical examination skills and more importantly to act on the findings. An examination of referrals made from child health surveillance reviews in the first 18 months has shown a high false positive rate for a number of key conditions. ${ }^{9}$ Regular review of referral guidelines and developing more accurate screening tools could prevent unnecessary parental anxiety and hospital appointments.

(3) TO ENSURE EQUITABLE DELIVERY OF THE PROGRAMME AND THAT "HARD TO REACH" CHILDREN AND THOSE LOOKED AFTER ARE NOT MISSED BY THE UNIVERSAL PROGRAMME There are a number of vulnerable groups of childrentravellers, asylum seekers, those looked after by the local authority - who are at risk of not being provided with the mainstream package of preventive care. An "enhanced" service is required to reach these children, often using the expertise of health visitors and school nurses. ${ }^{10-12}$ Targeting health visitor resources and improving access to preventive 
Table 2 Suggested model for quality standards and outcome measures for child health surveillance

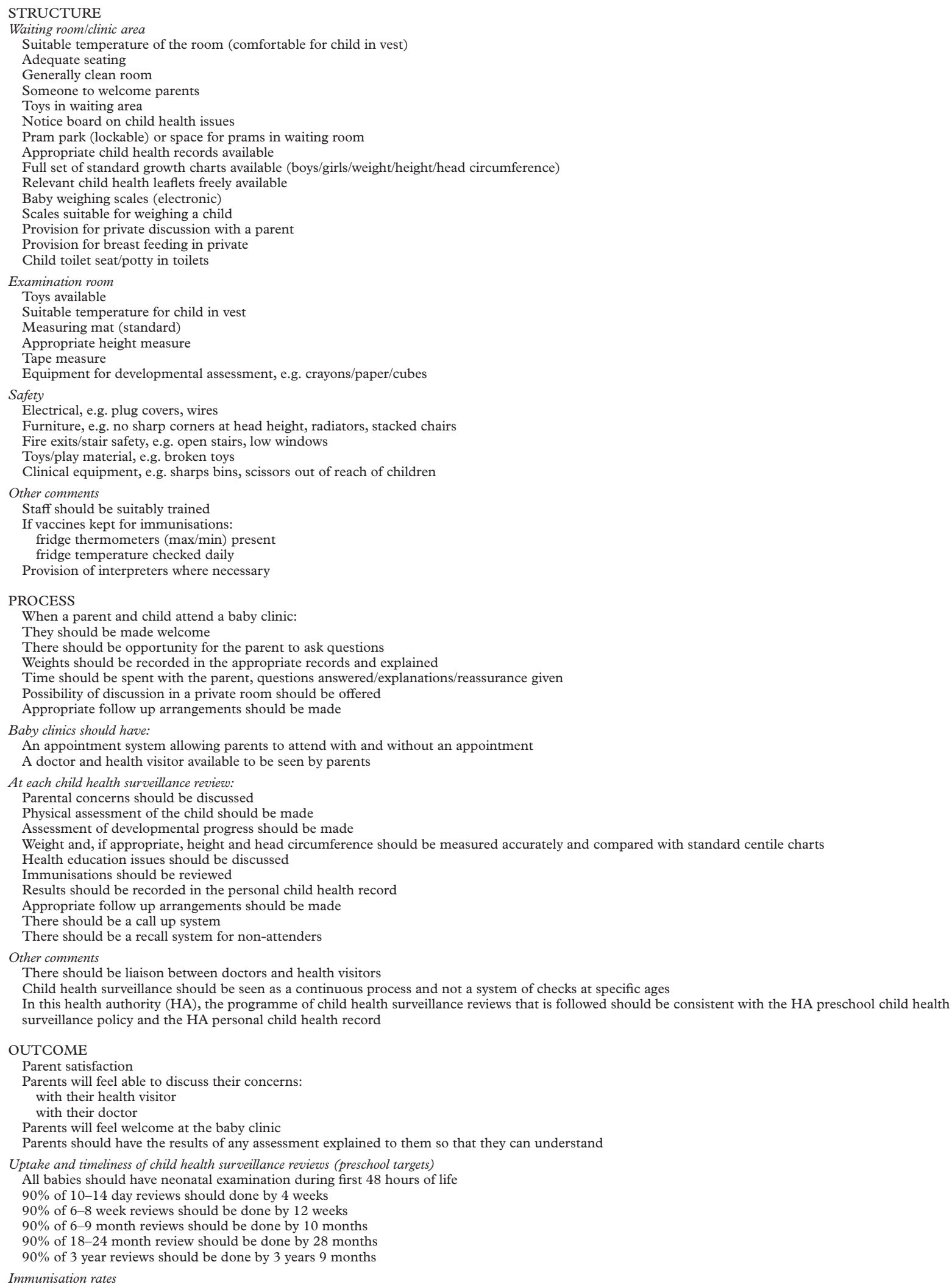

Adapted from Blair ME, Hampshire A, Crown N, et al. An audit of preschool child health surveillance in Nottingham 1993-6. Final report. London: Department of Health, 1997. 
services for those living in disadvantaged circumstances can help to reduce health inequalites. ${ }^{13}{ }^{14}$

(4) TO INTRODUCE AND COORDINATE NEW PROGRAMMES AND ALTERATIONS TO EXISTING PROGRAMME

As technology advances, there is a need to re-evaluate the relevance of the existing programme and consider the cost benefit aspects of new screening tools, for example, tandem mass spectroscopy, ${ }^{15}$ and programmable otoacoustic emissions for neonatal hearing screening. ${ }^{16}$ Alongside this is the consideration of how best to manage change in the way individuals work with appropriate explication, training, and monitoring of the proposed programme modifications.

(5) ESTABLISH, DEVELOP, AND MAINTAIN INFORMATION SYSTEMS

This is an essential aspect of monitoring the programme as above. The coordinator has to develop a close link with child health and hospital information systems managers in order to exploit the potential they give for monitoring and audit. ${ }^{8}$ The NHS number will soon be issued from birth which will enable tracking of infants in the first few weeks of life. This may help improve the monitoring of the neonatal biochemical screening programme-a process which has been found deficient. ${ }^{17}$

An accurate integrated district special conditions register will allow for retrospective audits to be completed on children with cerebral palsy, significant sensory impairment, and those with long standing illness, and facilitate screening programme enhancement. ${ }^{18}$

The "overview" function which was discussed earlier will be made possible with the adoption of an interagency "child health core data set". ${ }^{19}$ This has the potential for forming the basis of an annual report for health authority, providers, and voluntary organisations, informing future service development and monitoring health improvement programmes for children. ${ }^{20}$ Most of the systems above are for the benefit of health providers. ChildServe is a preventive programme set up by Paul Dworkin in Connecticut, USA and allows access for both children and families to a computerised inventory of services and programmes to promote development. ${ }^{21}$

(6) TO FACILITATE CONSULTATION WITH PARENTS, CHILDREN, AND VOLUNTARY GROUPS IN THE PLANNING AND

IMPLEMENTATION OF THE PROGRAMME

Parents are often the first to suspect a problem in their child's health and development. Well produced parent information can support early detection of an impairment, help prevent accidents, and promote immunisation uptake. ${ }^{22}$ Parent information leaflets and guidance are produced for the parent held record and for distribution in health centres and hospitals. It is important to keep these up to date with changes in the national programme and relevant for the local population's needs. Feedback from parent and voluntary groups needs to be actively sought by the steering group to ensure parentally relevant outcomes such as "reassurance of normality", "privacy for breast feeding", and "safe pram parking" are built into the programme monitoring cycle. ${ }^{23}$

\section{Summary and conclusions}

A programme of preventive and clinical care involves many people, often from different agencies and organisations. The goals have to be clear along with individual and corporate responsibilities. The role of the child health surveillance coordinator is to bring these elements together to ensure provision of an up to date, evidence based, acceptable, and effective programme.

I would like to thank my colleagues Drs Janet Chaplais, Rashmin Tahmne, and Fawzia Rahman, Leon Polnay, David Hall, Martin Bax, and Claire Burns who helped me to develop these concepts over many years.

\section{MITCH BLAIR}

Senior Lecturer in Paediatrics and Child Health,

Department of Paediatrics, Imperial College School of Medicine and

Northwick Park Hospital (North West London Hospital NHS Trust),

Harrow, Middlesex HA1 3UF, UK

m.blair@ic.ac.uk

1 Charlton BG. The ideology of "accountability". $\mathcal{F} R$ Coll Physicians Lond 1999;33:33-5.

2 Court SDM. Fit for the future. Report of the Committee on Child Health Services. London: HMSO, 1976.

3 BPA/FPH. Working together for tomorrow's children. A discussion document from a joint working party of the Faculty of Public Health Medicine and the British Paediatric Association. London: BPA/FPH, 1990.

4 Hall D, ed. Health for all children. Report of the Third foint Working Party on Child Health Surveillance, 3rd edn. Oxford: Oxford University Press, 1996. 5 Polnay L, ed. Health needs of the school age child. Report of a foint Working Party of the British Paediatric Association. London: BPA, 1995.

6 Polnay J, Blair M. Child protection training for GPs - a model programme for busy learners. Child Abuse Review 1999;8:284-8

7 Hampshire A, Blair M, Crown N, Avery A, Williams I. Action research: a useful method of promoting change in primary care? Fam Pract 1999;16:305-11.

8 Logan S. Outcome measures in child health. Arch Dis Child 1991;66:745-8. 9 Hampshire A, Blair M, Crown N, Avery A, Brackenbury P, Williams I. Is pre-school child health surveillance an effective means of detecting key physical abnormalities? Br f Gen Pract 1999;46:630-3.

10 Kendrick D, Elkan R, Hewitt M, et al. Does home visiting improve parenting and the quality of the home environment? A systematic review and ing and the quality of the home environmen
meta-analysis. Arch Dis Child 2000;82:443-51.

11 Polnay L, Glaser AW, Dewhurst T. Children in residential care; what cost? Arch Dis Child 1997;77:394-5.

12 Van Cleemput P. Health care needs of travellers. Arch Dis Child 2000;82: 32-7.

13 Reading R, Allen C. The impact of social inequalities in child health on health visitors' work. F Public Health Med 1997;19:424-30.

$14 \mathrm{Ni}$ Bhrolchain CM. Will deprived areas still need community paediatricians? An unpopular hypothesis. Public Health 1994;108:319-26.

15 Seymour CA, Thomason MJ, Chalmers RA, et al. Newborn screening for inborn errors of metabolism: a systematic review. Health Technol Assess 1997;1.

16 Davis A, Bamford J, Wilson I, Ramkalawan T, Forshaw M, Wright S. A critical review of the role of neonatal hearing screening in the detection of congenital hearing impairment. Health Technol Assess 1997;1.

17 Streetly A, Grant C, Pollitt RJ, Addison GM. Survey of scope of neonatal screening in the United Kingdom. BMF 1995;311:726.

18 Woodroffe C, Abra A. A special conditions register. Arch Dis Child 1991;66: 927-30.

19 CHIC. Monitoring the health of our nation's children. Key indicators and the underlying essential core data set. www.chiconsortium.org.uk April 2000.

20 UK government White Paper. Saving lives: our healthier nation. London: HMSO, 1999

21 ChildServ. Centre for Children's Health and Development, St Francis Hospital and Medical Center. Annual report. Hartford, CT: ChildServ, 1999.

22 Glascoe FP, Oberklaid F, Dworkin PH, Trimm F. Brief approaches to educating patients and parents in primary care. Pediatrics 1998;101:E10.

23 Hampshire A, Blair M, Crown N, Avery A, Williams I. Assessing the quality of child health surveillance in primary care. What are the problems? Ambulatory Child Health. In press. 